\title{
Reuse of red ceramic waste in the production of concrete for civil construction
}

\author{
Reutilização de resíduos de cerâmica vermelha na produção de concreto para a construção civill \\ Reutilización de residuos cerámicos rojos en la producción de hormigón para construcción civil
}

Received: 09/23/2021 | Reviewed: 09/27/2021 | Accept: 09/28/2021| Published: 09/30/2021

Heberson Teixeira da Silva

ORCID: https://orcid.org/0000-0001-9163-6984

Federal University of the Jequitinhonha and Mucuri Valleys, Brazil

E-mail: hebersonteixeirasilva@gmail.com

Luély Souza Guimarães

ORCID: https://orcid.org/0000-0001-8817-7326

Federal University of the Jequitinhonha and Mucuri Valleys, Brazil

E-mail: luelyguimaraes@hotmail.com

Fernanda Andrade Dutra

ORCID: https://orcid.org/0000-0001-6018-8904

Federal University of the Jequitinhonha and Mucuri Valleys, Brazil

E-mail: fernanda-dutraa@hotmail.com

Dayanne Caldeira Martins

ORCID: https://orcid.org/0000-0001-5442-3429

Federal University of the Jequitinhonha and Mucuri Valleys, Brazil

E-mail: dayanne.caldeira@ufvjm.edu.br

Dilceu Silveira Tolentino Júnior

ORCID: https://orcid.org/0000-0003-2435-7576

Federal University of the Jequitinhonha and Mucuri Valleys, Brazil

E-mail: dilceujunior@bol.com.br

Alexandre Sylvio Vieira da Costa

ORCID: https://orcid.org/0000-0001-7251-7816

Federal University of the Jequitinhonha and Mucuri Valleys, Brazil

E-mail: alexandre.costa@ufvjm.edu.br

Stênio Cavalier Cabral

ORCID: https://orcid.org/0000-0001-5241-9776

Federal University of the Jequitinhonha and Mucuri Valleys, Brazil E-mail: stenio.cavalier@ufvjm.edu.br

Lucas Ferreira Freitas

ORCID: https://orcid.org/0000-0001-6826-6970

Federal University of the Jequitinhonha and Mucuri Valleys, Brazil E-mail: lucas.freitas@ufvjm.edu.br

\begin{abstract}
In search of the reuse of waste from civil construction, studies are presented as an alternative on the insertion of this waste into materials so that they become ecologically viable and at a lower cost. In this scope, there is the red ceramic waste $(\mathrm{RCW})$, which is largely produced both in renovation works and in the stage of transporting construction components such as bricks, slabs, and floors. On the other hand, the use of cement is of great proportions, which raises concerns about the excessive consumption of non-renewable natural resources, especially in large-scale projects. Thus, the study aimed to evaluate the mechanical properties of compressive strength of concrete with partial replacement of cement by RCW and to verify the influence at different breakage ages $(7,14,21$, and 28 days). Five mixes were used, the first with $100 \%$ cement, and the others with crushed RCW to replace $5 \%, 10 \%, 15 \%$, and $20 \%$ of the cement, and the resistance obtained according to percentages and ages was also verified of RCW through the uniaxial compression test. Thus, it was observed that for replacements of up to $15 \%$, the strength losses were not significant, suggesting the feasibility of its use in works with high concrete demands, such as in dams.
\end{abstract}

Keywords: Concrete; Red ceramic waste; Portland cement.

\section{Resumo}

Em busca do reaproveitamento de resíduos provenientes da construção civil, apresentam-se como alternativa estudos sobre a inserção desses detritos em materiais para que se tornem ecologicamente viáveis e de menor custo. Neste âmbito, encontra-se o resíduo de cerâmica vermelha $(\mathrm{RCV})$ que é largamente produzida tanto em obras de reformas quanto na etapa de transporte de componentes construtivos como tijolos, lajotas e pisos. Em contrapartida, a utilização do cimento é considerada de grandes proporções, o que causa preocupações quanto ao consumo excessivo dos recursos naturais não-renováveis, principalmente em obras de grande vulto. Dessa forma, o estudo objetivou avaliar as propriedades mecânicas de resistência à compressão de concretos com substituição parcial do cimento pelo RCV e verificar a influência em diferentes idades de rompimento (7, 14, 21 e 28 dias). Foram utilizados cinco traços, sendo o primeiro 
com $100 \%$ de cimento, e os demais com o RCV triturado em substituição de 5\%, 10\%, $15 \%$ e $20 \%$ do cimento, sendo também verificado a resistência obtida conforme as porcentagens e as idades de RCV através do ensaio de compressão uniaxial. Assim, observou-se que para substituições de até $15 \%$ às perdas de resistência não foram significativas, sugerindo a viabilidade de sua utilização em obras com grandes demandas de concreto, como em barragens.

Palavras-chave: Concreto; Resíduo de cerâmica vermelha; Cimento Portland.

\section{Resumen}

En busca de la reutilización de residuos de construcción civil, se presentan como alternativa estudios sobre la inserción de estos residuos en materiales para que sean ecológicamente viables y a menor costo. En este ámbito, se encuentra el residuo cerámico rojo (RCR), que se produce mayoritariamente tanto en obras de rehabilitación como en la etapa de transporte de componentes de construcción como ladrillos, losas y suelos. Por otro lado, se considera que el uso de cemento es de grandes proporciones, lo que genera preocupación por el consumo excesivo de recursos naturales no renovables, especialmente en proyectos de gran envergadura. Así, el estudio tuvo como objetivo evaluar las propiedades mecánicas de resistencia a compresión del hormigón con sustitución parcial de cemento por RCR y verificar la influencia en diferentes edades de rotura (7, 14, 21 y 28 días). Se utilizaron cinco mezclas, la primera con cemento $100 \%$, y las otras con RCR triturado para reemplazar el 5\%, 10\%, 15\% y 20\% del cemento, y también se verificó la resistencia obtenida según porcentajes y edades. De RCR mediante la prueba de compresión uniaxial. Así, se observó que para reemplazos de hasta $15 \%$, las pérdidas de resistencia no fueron significativas, sugiriendo la factibilidad de su uso en obras con altas demandas de hormigón, como en presas.

Palabras clave: Hormigón; Residuos de cerámica roja; Cemento Portland.

\section{Introduction}

The advancement of technologies and the growth of the world population is linked to the increase in the consumption of natural resources and energy on the planet, as a result, some resources are in scarcity. Thus, with global challenges, it is necessary to position companies and the population in general, in order to promote changes with regard to sustainable practices in order to minimize environmental disasters and the lack of resources, today and in the future (Augustin, Rodrigues \& Leonardelli, 2014; Spinelli, Alves \& Konrad, 2013).

Sustainable development is necessary from a global perspective, as this practice makes it possible to meet the basic needs of the population and ensure that everyone has favorable living conditions on the planet, which allows for technological, social, economic and environmental advances in the current and future spheres. of the timeline, without compromising the quality of life in both phases (Brasileiro \& Matos, 2015).

The Civil Construction Industry is one of the main socioeconomic activities in the country, however, it is the largest provider of environmental impacts, in which it consumes between 20 and $50 \%$ of the planet's natural resources. In Brazil, this sector has a strong influence as it represents about $15 \%$ of the Brazilian gross domestic product (GDP), and, nationally, the impacts are associated with high energy consumption, pollution generated in most processes, as well as, in the final phase, for example in the maintenance of buildings (Brasileiro \& Matos, 2015).

In Brazil, the estimated amount of generation of construction and demolition waste (CDW) per year is over 70 million tons per year, which corresponds to more than $50 \%$ of the mass of urban solid waste produced, however, only $20 \%$ it is recycled (Contreras et al., 2015). Thus, a possible solution in order to minimize the negative impacts would be the recycling of construction and demolition waste and its reuse in civil construction itself as an alternative raw material (Cabral, 2007).

In his literature, Cabral (2007) points out the waste of ceramic floors and coverings in works, being around $12 \%$ to $22 \%$. Therefore, given the data, it appears that an adequate solution would be the reuse of red ceramic waste and its insertion in the production chain itself.

A sector of great contribution in civil construction is infrastructure, which offers basic conditions for survival. Given the development of this sector, a considerable increase in the demand for materials to be used is conceivable, which configures a concern in relation to natural resources and the destination of the waste generated in the process.

Another perspective is in relation to concrete dams, which use large amounts of this input in their composition, which takes up another problem faced in the civil construction sector - cement production. In this sense, regarding the selection of 
materials, Neville, and Albuquerque (1997, 2009) recommend the use of mineral additions, partially replacing the cement volume. In this way, the additions reduce the heat generated at the initial ages, since the amount of clinker present in the mixture is smaller, and a good part of the hydration reactions start to occur at more advanced ages, inhibiting cracks.

Therefore, in an attempt to minimize the negative impacts of civil construction on the environment and contribute to environmental and economic benefits from the reuse of materials, this study proposes the addition in mass fractions of $5 \%, 10 \%$, $15 \%$ and $20 \%$ of RCV as a partial substitute for cement without damaging the strength and durability of the buildings in question.

\subsection{Concrete used in dams}

Concrete structures must be designed and built to meet specific purposes during their useful life, considering direct costs and preventive and corrective maintenance. In the case of large-scale works, especially, such as dams, these requirements must be taken into account from the first stages of the study, as they demand large investments, labor and the elaboration of judicious projects (Verly, 2015).

The Ministry of National Integration - MIN (2002), through the Dam Safety and Inspection Manual, defines a dam as a structure built across a river or thalweg, with the purpose of obtaining the elevation of its water level and/or to create a reservoir for the accumulation of water, whether regulating the flow of the river or other fluid.

Dams can have multiple purposes, such as: supply and irrigation, regularization of water courses, generation of electricity, protection against floods, containment of tailings, navigation, fish farming, recreation and others. From an economic point of view, they are important sources of energy for countries with high hydroelectric potential. China, India and Brazil are the countries that most use dams as a source of energy and water security (EPE, 2011; IEA, 2012; Costa, 2016).

Used for dam structures, mass concrete, according to Albuquerque (2005), has its structures designed based on stability, durability, economy and thermal behavior, with resistance often being a secondary requirement. In summary, the concrete to be used in dams must meet, according to Vieira Jr \& Salles (2011), a series of physical, mechanical, and even chemical requirements, such as compressive strength, permeability in contact with water, abrasion resistance due to the passage of water at speed and the presence of suspended sediments, among others.

\subsection{Waste from construction and demolition (WCD)}

The Resolution Number 307 of the National Environmental Council, which aims to establish guidelines, criteria, and procedures for the management of civil construction waste, provides in its article 2, paragraph I that:

Civil construction waste: those arising from constructions, renovations, repairs, and demolitions of civil construction works, and those resulting from the preparation and excavation of land, such as bricks, ceramic blocks, concrete in general, soils, rocks, metals, resins, glues, paints, wood and plywood, ceilings, mortar, plaster, tiles, asphalt pavement, glass, plastics, piping, electrical wiring, etc., commonly called construction debris, limestone or shrapnel (CONAMA, 2002, p. 1).

According to John (2000), the volume of natural resources used by civil construction, many of them non-renewable, corresponds to at least one-third of the total consumed annually by society as a whole. The sector consumes around 210 million tons per year of natural aggregates just for the production of concrete and mortar.

The lack of recycling management of these natural resources may compromise, in the near future, the current way of life of societies (SENAI, 2005), and therefore, an important mechanism to be used in this issue is the implementation of programs for the management of these residues.

In order to make this program more effective, based on resolution 307 (CONAMA, 2002), four classes of civil construction waste have been defined, which must have different treatments: Classes A, B, C, and D as presented in Table 1 . 
Table 1. Classification of Construction and Demolition Residues.

Class Description

\begin{tabular}{ll}
\hline & $\begin{array}{l}\text { Reusable or recyclable waste such as aggregates, construction, demolition, } \\
\text { renovations, or repairs, such as a) paving and other infrastructure works, including } \\
\text { Class A }\end{array}$ \\
& $\begin{array}{l}\text { soil from earthworks; b) of buildings: ceramic components (bricks, blocks, tiles, } \\
\text { cladding boards, etc.), mortar and concrete; c) the manufacturing and/or demolition } \\
\text { process of precast concrete parts (blocks, tubes, curbs, etc.) produced at construction } \\
\text { sites. }\end{array}$ \\
\hline Class B & $\begin{array}{l}\text { Recyclable waste for other destinations, such as plastics, paper, cardboard, metals, } \\
\text { glass, wood, and plaster. }\end{array}$ \\
\hline Class C & $\begin{array}{l}\text { Waste for which economically viable technologies or applications that allow } \\
\text { recycling or recovery have not been developed. }\end{array}$ \\
\hline Class D & $\begin{array}{l}\text { Hazardous waste from the construction process, such as paints, solvents, oils, and } \\
\text { others, or those contaminated from demolitions, renovations, and repairs of } \\
\text { radiological clinics, industrial facilities, and others. }\end{array}$ \\
\hline
\end{tabular}

Source: CONAMA 307 (2002).

In the composition of CDW, according to Cabral (2007), mortar, concrete and ceramic materials account for $62 \%$ of the total CDW in Brazilian cities, characterizing class A as the one with the greatest potential for application.

\subsection{Red ceramic waste $(\mathrm{RCW})$}

The Red ceramic is characterized by-products from clay and gives rise to various constructive components, such as tiles, tiles, blocks, bricks, coatings, among others, and because it is a fragile material, they collapse easily, generating a large amount of debris, either in buildings or even in renovations.

Among the CDWs classified as type A, we have red ceramic waste $(\mathrm{RCW})$, which in turn characterizes an industrial sector of expressive production in the country and configures a waste with a clear potential for reuse.

Jerônimo et al. (2012), shows that the red ceramic industry can provide this residue from product breakage during handling and transport since although there is no official data, the literature reports loss values of around $10 \%$ of the material produced. This residue, under certain conditions, can have pozzolanic characteristics, which, similar to cement, play an important role in the composition of concrete due to the filler effect, which acts on its structure, occupying the empty spaces left by the larger grains.

Among the main harmful impacts on the environment, resulting from the red ceramic industry, the extraction of natural resources, the generation of solid waste, and gaseous emissions stand out. Thus, Moura (2008) guides to reduce waste that is generated irregularly, always looking for a better option, improving the performance of constructions regarding the generation of these wastes, as well as using reuse techniques that are linked to the idea of valuing the waste and reuse it, adding value to it.

\section{Materials and Methods}

The study is characterized as experimental research, as some variables related to the object of study were manipulated in order to find the best result for concrete strength (Fonseca, 2002; Silveira \& Córdova, 2009). Thus, a literature review was carried out to define the dosage of concrete mixes, as according to Helene and Terzian (1992) they constitute a necessary procedure to obtain the best mix among the materials that are part of the concrete. The ideal proportion of materials that make up the traces was expressed in dry mass of materials in the following order: (cement/sand/gravel/water). Through studies for the 
manufacture of conventional mass concrete, with a strength of $25 \mathrm{MPa}\left(\mathrm{kgf} / \mathrm{cm}^{2}\right)$ at 28 days of cure, a ratio was reached: (1:1.98:3.23: 0.61) adopted as the primary proposal, which had its base composition multiplied to meet the quantity demanded all conditions, with expected breakage ages of 7, 14, 21 and 28 days.

The experimental planning took place in the subdivision of five distinct traits, namely, the reference (T1) and subsequent traits (T2, T3, T4, and T5), subjected to fractions of cement replacement by RCW of 5\%, 10\%, $15 \%$, and $20 \%$ respectively, in percentage by mass. These subdivisions make it possible to analyze, with greater scope, the influence of replacement percentages on the material's properties and thus present the feasibility of reusing this waste.

The test bodies (TBs) were manufactured following NBR 7223, using fine and coarse aggregates, Portland cement (TBIII), crushed red ceramic waste (RCW), and water. The RCW came from leftover material from the renovation of a residential project, the cement used was from the Cauê TB III 40 RS brand of blast furnaces, and the other items were donated by Concreteira Mix Mattar.

The constituents were weighed using a digital scale and the mixture was made with the aid of a concrete mixer. Then, the concrete was inserted into the metallic cylindrical molds with dimensions of $10 \mathrm{~cm}$ in diameter and $20 \mathrm{~mm}$ in height, being arranged in two layers with a manual rebate of 12 strokes in each of them using a compaction rod, which had as objective to reduce its porosity as much as possible and taking care that it does not suffer segregation, according to the recommendations of the standard, NBR 5738.

The rectification of the test body was carried out with a Stuhlert brand grinding machine following NBR 5738, with the removal of $0.1 \mathrm{~mm}$ of the material's outer layer. Thus, the removal took place in $0.05 \mathrm{~mm}$ at each end (top and base), enabling geometric control and providing the test body with a smooth surface to obtain greater precision in the results.

The simple compressive strength was determined by the recommendations of NBR 5739, where the TBs were broken, using a digital electric press, brand Solocap, with a maximum load of $1000 \mathrm{KN}$. Then the strength of each TB at 7, 14, 21, and 28 days of cure was calculated, according to equation 1.

$$
\mathrm{fck}(\mathrm{MPa})=\left(\frac{\frac{\mathrm{fck}(\mathrm{KN})}{\mathrm{Acp}}}{9,81}\right) * 100 \mathrm{Eq} .1
$$

Where:

CSC: Characteristic strength of concrete.

TBA: Test body area.

\section{Results and Discussion}

The relationship between water and cement, called factor (W/C) is of paramount importance for the quality of concrete due to its direct influence on its strength. Typically, the water/cement factor is between 0.4 and 0.7 . In the studied mix, $1 \mathrm{~kg}$ of cement and $0.61 \mathrm{~kg}$ of water were used, so the ratio used was 0.61 , which is within the normal range, and a satisfactory concrete consistency was obtained for the elaboration of the TB's.

Table 2 and Figure 2 present the values found for the compressive strength of the twenty TB's produced with the different traits shown throughout the work. 
Table 2. Resistance of each TB in relation to days of cure.

\begin{tabular}{ccccc}
\hline \multirow{2}{*}{ Trace } & \multicolumn{4}{c}{ Resistance of test body (MPa) } \\
\cline { 2 - 5 } & 7 days & 14 days & 21 days & 28 days \\
\hline T1 & 14.58 & 15.83 & 19.07 & 20.4 \\
T2 & 16.35 & 14.13 & 18.68 & 20.03 \\
T3 & 12.61 & 14.87 & 18.05 & 19.65 \\
T4 & 9.76 & 12.54 & 17.16 & 18.84 \\
T5 & 11.63 & 12.3 & 13.9 & 15.37 \\
\hline
\end{tabular}

Source: Authors (2021).

The results will also be presented through comparative graphs between the reference mix (without cement replacement) and the mixes where it was replaced by crushed ceramic waste.

Figure 1. Comparison between traits with different proportion of RCV.

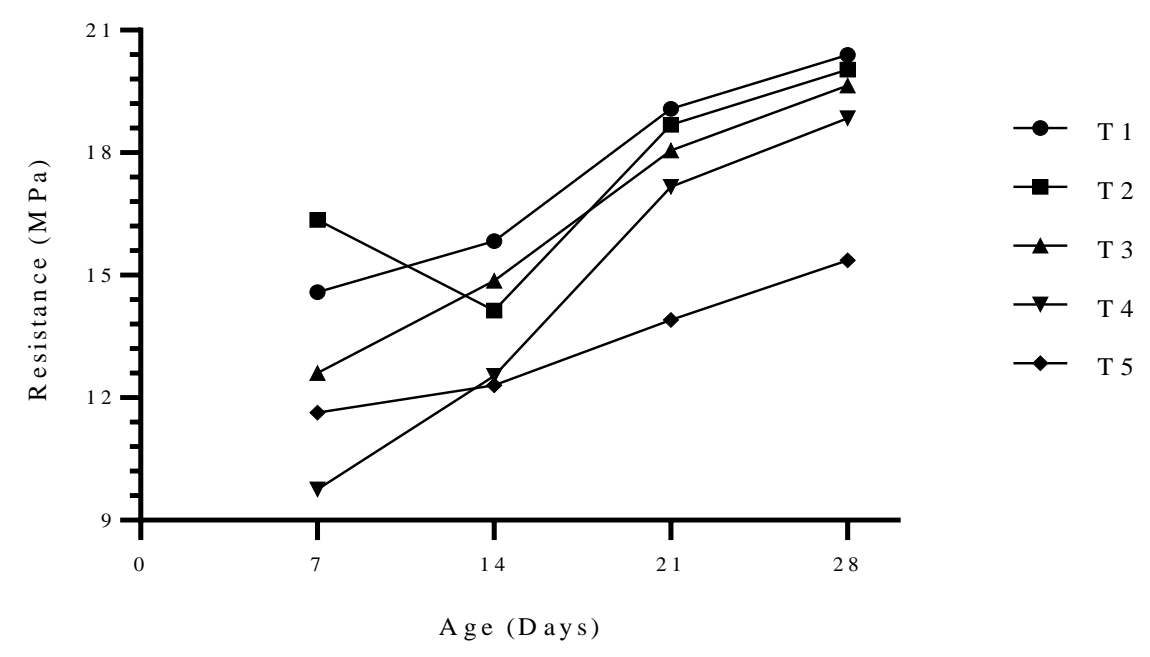

Source: Authors (2021).

It is observed in Figure 1, at first, the period corresponding to seven days of cure of the T2 trait, which presented a satisfactory result. With a compressive strength of $16.35 \mathrm{MPa}$ it was obtained a value above $60 \%$ of the value calculated for the $25 \mathrm{Mpa}$ mix due to the curing time, it should be noted that the compressive strength of the T1 mix was higher when compared. On subsequent dates, the compressive strength values of the mixes were evened out, showing little significant difference, thus, both reached a similar and satisfactory value at 28 days of cure.

Initially, after seven days of curing, the T3 mix showed compressive strength below the T1 mix, a difference that decreases with the increase in curing time. At the end of 28 days, the T3 mix presented a compressive strength value very close to that of the T1 test mix, with little significant difference.

It is observed that the T4 mixture initially presents, after seven days of curing, a value of compressive strength below the expected considering the curing time, and the $9.76 \mathrm{MPa}$ represents $39 \%$ to the value calculated for the reference mixture, the difference decreases with increasing healing time, especially after 21 days.

It is evident, for $\mathrm{T} 1$ and $\mathrm{T} 5$, the increase in the difference between the compressive strengths of the test mix when compared to those that underwent replacement of cement by RCW. Different from the results presented above, the T5 mix 
presents a considerable difference in the compressive strength on the seventh day when contracted to the T1 mix, which remains until 28 days, where it presents approximately $24 \%$ strength when compared to the test mix.

Figure 2 shows the TB's with replacement of cement by RCW of a) $5 \%$, b) $10 \%$, c) $15 \%$ and d) $20 \%$, broken after 7 days of cure on $21 / \mathrm{Jul} / 18$. It is possible to observe that the red dots come from the crushed ceramic, which in turn has more evidence on the TB surface as the percentage of RCW in the mix increases.

Figure 2. Test bodies with 7 days of cure.

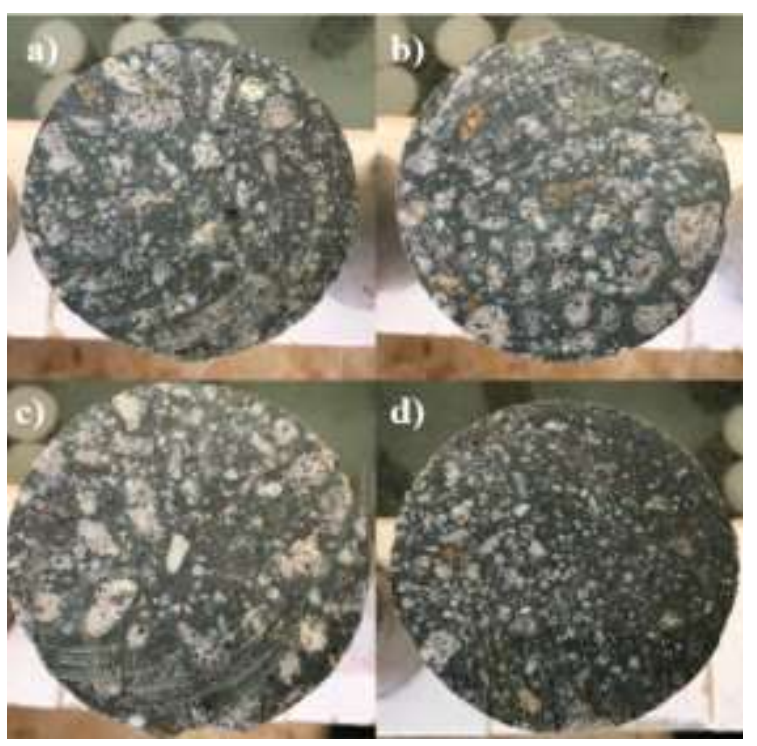

Source: Authors (2021).

Figure 3, on the other hand, illustrates the TB's in the same sequence shown in the previous image, however containing TB's ruptured with 14 days of cure on July 28, 2018. It is possible to notice that with more days of cure the TB's started to have a darker color.

Figure 3. Test bodies with 14 days of cure.

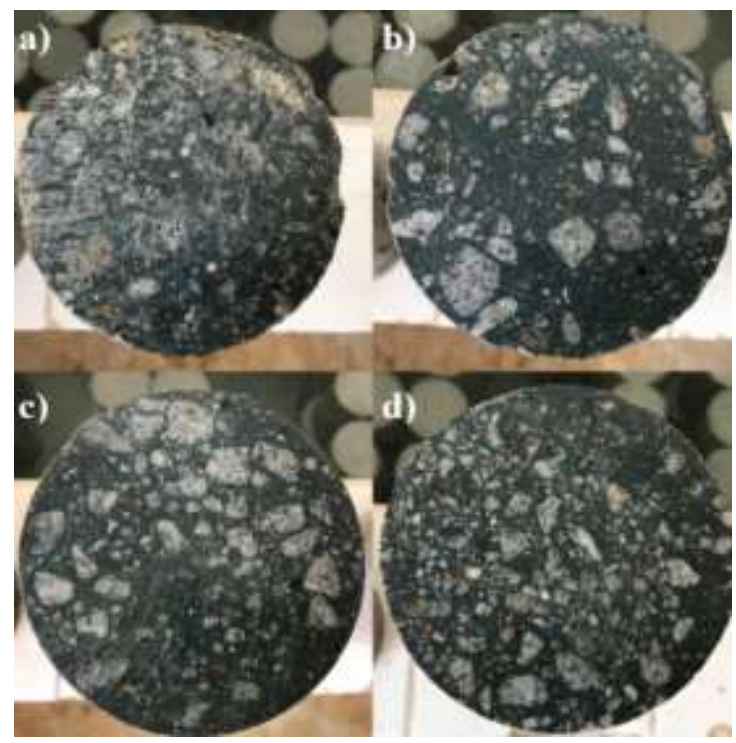

Source: Authors (2021). 
Figure 4 shows the TB's with replacement of cement by RCW of a) $5 \%$, b) $10 \%$, c) $15 \%$ and d) $20 \%$ broken at 21 days on August 4, 2018.

Figure 4. Test bodies with 21 days of cure.

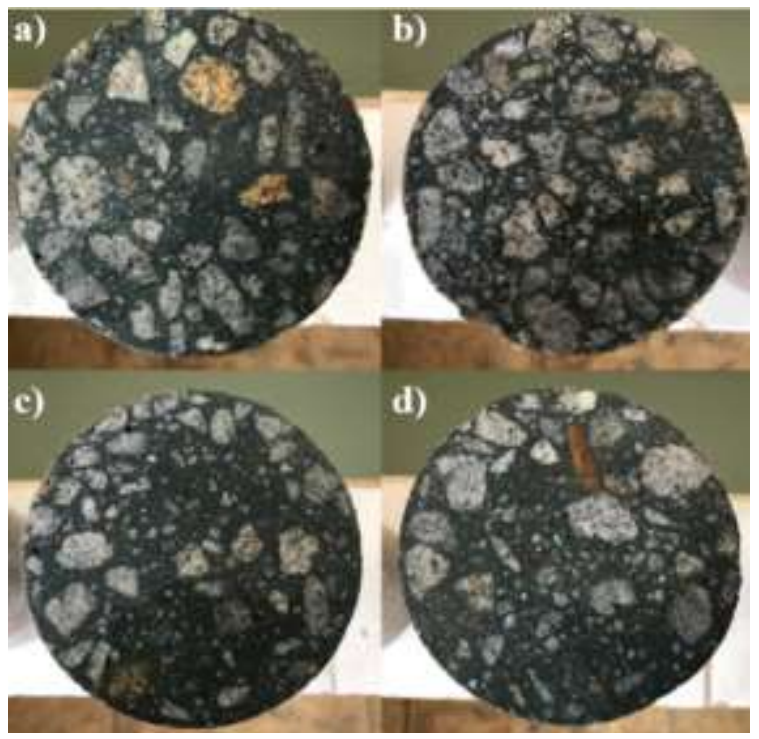

Source: Authors (2021).

And finally, Figure 5 illustrates, in the same sequence shown in the previous image, containing, however, the TB's ruptured at 28 days of cure, on August 11, 2018.

Figure 5. Test bodies with 28 days of cure.

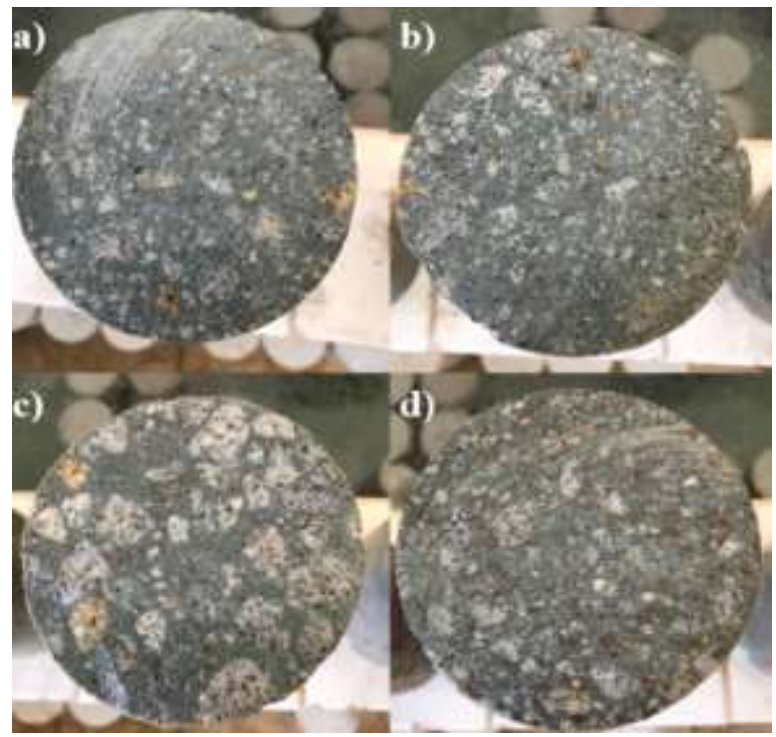

Source: Authors (2021).

\section{Conclusion}

The residues from renovations or breakages of red ceramic floors make up a large volume of raw materials that can be used in the composition of common building materials, such as concrete, bringing environmental and economic gains as the amount of cement used decreases, in addition to proposing a means of recycling it so that it is not disposed of inappropriately in 
the environment.

The incorporation of red ceramic waste can be an efficient alternative to minimize the use of cement in large works, since it is a non-renewable natural raw material, in addition to contributing to a reduction in the heat generated in the reaction of cement hydration, responsible for the cracking of concrete at younger ages and which are undesirable in dam structures.

Based on the results obtained, the mixes that have a replacement of cement by RCW in up to $15 \%$ have compressive strength values very close to the reference mix, this satisfactory result indicates that they can be used in any structural work, such as beams, pillars, slabs, or even in dams. Although all traits had lower resistance results than their respective reference traits, there is a tendency for this negative effect to decrease with advancing age, which may be a consequence of subsequent pozzolanic reactions.

Another alternative use is for possible traits that have a ratio of cement replacement by RCW greater than $15 \%$, because, despite having an unsatisfactory compressive strength, these composites can be formulated for low structural requirements, as in elements fence, sidewalks, among others, resulting in greater use of the RCW.

Thus, it can be concluded that the crushed red floor ceramic is ideal for the proposed replacement of cement, since in addition to the benefits brought by the pozzolanic addition, which are directly related to the decrease in porosity and permeability of the structures that contain this addition. In addition, the mass replacement of cement generates savings and, from the point of view of sustainability, results in a reduction in the consumption of natural raw materials in manufacturing, added to the recycling of RCW.

As a suggestion for future works, it is recommended a precise characterization of this residue in order to identify its constituents and their proportions so that a more precise planning of the dosage can be made in order to standardize the concrete traces depending on its use.

It is also proposed, studies on the variation of the ceramic waste particle size and also the water/cement factor used, to establish the ideal conditions for the use of ceramic waste as pozzolanic material in partial replacement of Portland cement. In addition, a cost-benefit study of the use of red ceramic waste, evaluating whether the implementation of a waste management program is feasible to reduce the costs invested in raw materials traditionally used in the manufacture of concrete.

\section{References}

Albuquerque, A. C., (2009). Estudo das propriedades de concreto massa com adição de partículas de borracha de pneu. Tese (Doutorado), UFRGS, Rio Grande do Sul, Brasil.

Albuquerque, A. C., Hasparyk, N. P., Andrade, M. A. S., \& De Andrade, W. P. (2005). Polymeric admixtures as bonding agent between tire rubber and concrete matrix. Special Publication, 229, p.479-496.

Augustin, S., Rodrigues, I. N., \& Leonardelli, P. P. (2014). A influência da densidade populacional no desenvolvimento sustentável. Sustentabilidade ambiental: estudos jurídicos e sociais, p. 89.

Brasileiro, L. L., \& Matos, J. M. E. (2015). Revisão bibliográfica: reutilização de resíduos da construção e demolição na indústria da construção civil. Cerâmica, 61, p.178-189.

Cabral, A. E. B., (2007). Modelagem de propriedades mecânicas e de durabilidade de concretos produzidos com agregados reciclados, considerando-se a variabilidade da composição do RCD. Tese (Doutorado), USP, São Carlos, SP, Brasil.

CONAMA - Conselho Nacional do Meio Ambiente (2002). Resolução No 307, de 5 de julho de 2002. Ministério das Cidades, Secretaria Nacional de Habitação. Publicada no Diário Oficial da União em 17/07/2002.

Contreras, M., Teixeira, S. R., Lucas, M. C., Lima, L. C. N., Cardoso, D. S. L., Silva, G. A. C., Gregório, G. C., Souza, A. E., \& Santos, A., (2016). Recycling of construction and demolition waste for producing new construction material (Brazil case-study). Construction and Building Materials, 123, p.594-600.

Costa, W. D., (2016). Geologia de barragens. Oficina de Textos.

EPE - Empresa de Pesquisa Energética (2011). Balanço energético nacional 2011. p.266. Rio de Janeiro.

Fonseca, J. J. S. Metodologia da pesquisa científica. Fortaleza: UEC, 2002. Apostila.

Helene, P. R. L., \& Terzian, P., (1992). Manual de dosagem e controle do concreto. São Paulo: PINI. 
Research, Society and Development, v. 10, n. 12, e536101220967, 2021

(CC BY 4.0) | ISSN 2525-3409 | DOI: http://dx.doi.org/10.33448/rsd-v10i12.20967

IEA - International Energy Agency (2012). Key world energy statistics. Paris: OCDE.

Jerônimo, V. L., Meira, G. B., Ferreira, P. R. R., Gonçalves, M. S., \& Filho, L. C. P. S., (2012). Produção de concreto com resíduos da indústria de cerâmica vermelha na Paraíba. Anais do $54^{\circ}$ Congresso Brasileiro do Concreto CBC, Alagoas.

John, V. M., \& Agopyan, V., (2000). Reciclagem de resíduos da construção. Seminário Reciclagem de Resíduos Sólidos Domésticos, 1(1), 01-13, São Paulo.

MIN - Ministério da Integração Nacional (2002). Manual de Segurança e Inspeção de Barragens. Ministério da Integração Nacional, Brasília, Distrito Federal.

Moura, L. A. A., (2008). Qualidade e gestão ambiental: sustentabilidade e implantação da ISO 14.001 (5a ed.). São Paulo.

NBR 5738 (2008): Concreto-Procedimento para moldagem e cura de corpos de prova. Rio de Janeiro.

NBR 5739 (1994): Concreto - ensaio de compressão de corpos-de-prova cilíndricos. Rio de Janeiro.

NBR 7223 - MB 256 - NM 67 (1996): Concreto - determinação da consistência pelo abatimento do tronco de cone. Rio de Janeiro.

NEVILLE, M. (1997). Propriedades do Concreto, Tradução Eng. ${ }^{\circ}$ Salvador E. Giammusso, $2^{a}$ edição rev. atual, Ed. Pini, São Paulo.

Salles, F. M., \& Vieira Jr, L. P., (2011). Tecnologia do concreto no projeto e construção de usinas hidrelétricas brasileiras. Revista Oficial do IBRACON. ISSN 1809-7197. São Paulo - SP.

SENAI, (2005). Gestão de Resíduos na construção Civil: Redução, Reutilização e Reciclagem.

Silveira, D. T., \& Córdova, F. P. (2009). A pesquisa científica. Métodos de pesquisa. Porto Alegre: Editora da UFRGS, 2009. p. 33-44.

Spinelli, R., Alves, A., \& Konrad, O. (2013). Cidade e Edificações: A busca por um novo modelo. Destaques Acadêmicos. Lajeado, 5(4), p.173-186.

Verly, R. C., (2015). Avaliação de metodologias de inspeção como instrumento de priorização de intervençães em obras de arte especiais. Dissertação (Mestrado)—UnB, Brasília, Brasil, 2015.

Vieira Jr., L. P., \& Salles, F. M., (2011). A Tecnologia do Concreto Aplicada ao Projeto de Barragens. Revista Concreto e Construções, 63, p.15-23. 